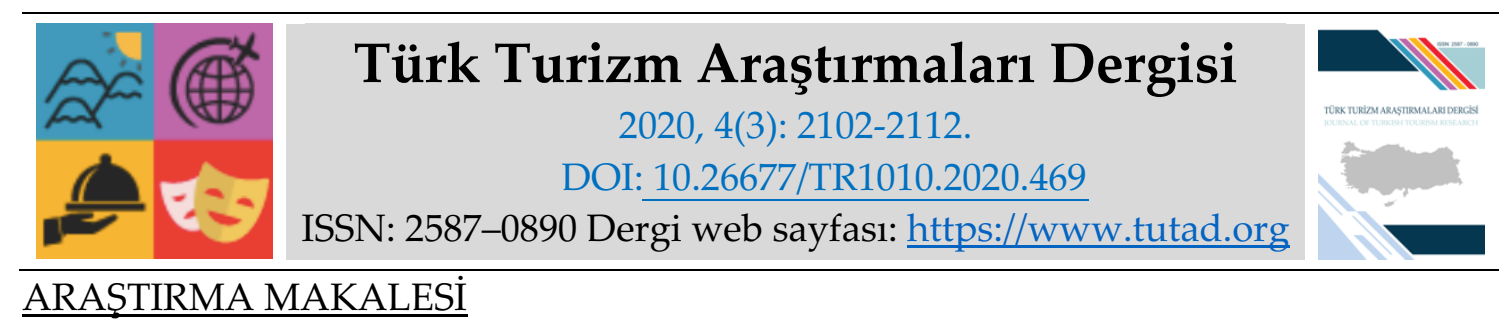

\title{
Destinasyon Sürdürülebilirliği Kapsamında De-Marketing Uygulamaları: Sapanca Destinasyonuna Dair Önleyici Bir Çalışma
}

Prof. Dr. Burhanettin ZENGIN, Sakarya Uygulamalı Bilimler Üniversitesi, Turizm Fakültesi, Sakarya, e-posta: bzengin@subu.edu.tr ORCID: https://orcid.org/0000-0002-6368-0969

Arş. Gör. Vahit Oğuz KİPER, Sakarya Uygulamalı Bilimler Üniversitesi, Turizm Fakültesi, Sakarya, e-posta: oguzkiper@subu.edu.tr ORCID: https://orcid.org/0000-0001-5558-2341

Öz

Bu çalışma Sapanca destinasyonunda gelecekte meydana gelmesi muhtemel taşıma kapasiteleri ve sürdürülebilirlik sorunlarına karşılık önleyici faaliyetler sunmak üzere tasarlanmıştır. Çalışmanın amacı bahsi geçen olası sorunlara karşı pazarlamama (de-marketing) uygulamaları ile bir dizi iyileştirici tedbirler geliştirmektir. Turizm destinasyonlarında sürdürülebilirlik ihmal edildiğinde destinasyonlar yaşam döngüsünde son evreye geçmekte, turizmin sağladığ avantajlar kaybedildiği gibi çevresel, ekonomik ve kültürel tahribat yaşanmaktadır. Bunun olmasını engellemek için önleyici ve giderici tedbirlere ihtiyaç duyulmaktadır. Bu çalışma ile Sapanca destinasyonunun mevcut durumu gözlenmiş ve analiz edilmiş, literatürdeki pazarlamama çalışmalarından derlenen veriler Sapanca destinasyonu özelinde uyarlanarak öneriler sunulmuştur. Bu önerilere göre Sapanca destinasyonu için taşıma kapasitelerini hesaplayan araştırmalara ihtiyaç vardır ve taşıma kapasitelerinin ilerleyen yıllarda turizm planlamasında hesaba katılması gerekmektedir. Sapanca destinasyonunun temel turizm çekiciliğinin doğal kaynakları olması nedeniyle, doğal kaynakların aşırı kullanıma bağlı deforme olmasını engellemek için kullanımı kısıtlayıcı pazarlamama uygulamalarına ihtiyaç duyulması ileriki yıllar için muhtemeldir.

Anahtar Kelimeler: Destinasyon Sürdürülebilirliği, Destinasyonlarda Pazarlamama, Önleyici Çalışma, Sapanca.

Makale Gönderme Tarihi: 12.03 .2020

Makale Kabul Tarihi: 04.07.2020

\section{Önerilen Atıf:}

Zengin, B. ve Kiper, V. O. (2020). Destinasyon Sürdürülebilirliği Kapsamında De-Marketing Uygulamaları: Sapanca Destinasyonuna Dair Önleyici Bir Çalışma, Türk Turizm Araştırmaları Dergisi, 4(3): 2102-2112.

(C) 2020 Türk Turizm Araştırmaları Dergisi. 


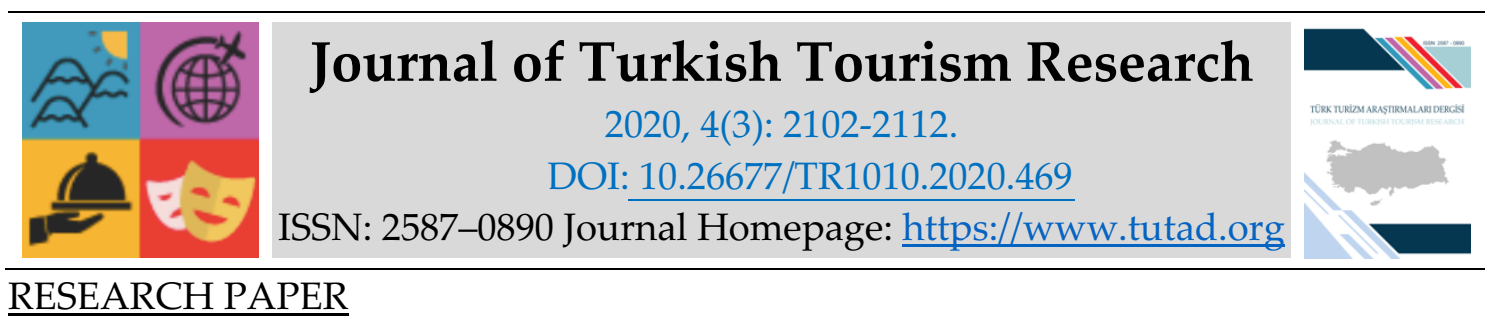

\title{
De-Marketing Implications for Sustainability of a Destination: A Preventive Research on Sapanca District
}

Prof. Dr. Burhanettin ZENGIN, Sakarya University of Applied Sciences, Faculty of Tourism, Sakarya, e-mail: bzengin@subu.edu.tr ORCID: https://orcid.org/0000-0002-6368-0969

Research Assistant Vahit Oğuz KIPER, Sakarya University of Applied Sciences, Faculty of Tourism,_Sakarya, e-mail: oguzkiper@subu.edu.tr

ORCID: https://orcid.org/0000-0001-5558-2341

\begin{abstract}
This paper is designed as a preventive research in order to possible threats of exceeding carrying capacities and sustainability limits in Sapanca destination. The aim of this paper is to present some improvements to that threat with demarketing tools. Ignoring sustainability results as destination reaching the last period of its life cycle and also losing all kinds of benefits from tourism. Also, cultural, economic and environmental damages come with it. To reverse that affects, preventive and corrective steps must be taken. Actual situation in Sapanca is observed and analized and data about demarketing are collected in literature to establish an accurate foundation for suggestion for Sapanca destination in the name of demarketing applications for destination sustainability. Further researches are needed in order to examine carrying capacities of the destination and those should be taken into consideration during tourism planning. Since natural resources are main attractiveness of the destinations, they must be protected gains overuse by demarketing tactics for the forthcoming years.
\end{abstract}

Keywords: Sustainability of Destinations, Demarketing in Destinations, Preventive Research, Sapanca.

Received: 12.03 .2020

Accepted: 04.07.2020

Suggested Citation:

Zengin, B. and Kiper, V.O. (2020). De-Marketing Implications for Sustainability of a Destination: A Preventive Research on Sapanca District, Journal of Turkish Tourism Research, 4(3): 2102-2112.

(C) 2020 Türk Turizm Araştırmaları Dergisi. 


\section{Gíriş}

Destinasyonlar; işletmeleri, yerel halkı, ziyaretçileri ve yerel karar vericileri ile birlikte canlı bir organizma gibidirler ve gerek bilinçli gerek istemsizce gelişip büyümek isterler. Bunun sonucunda turizmin getirilerinden daha fazla faydalanma peşinde olabilmektedirler. İşletmeler daha çok gelir elde etmek, yerel halk altyapı ve üstyapı imkânlarının gelişmesinin ve daha prestijli bir şehirde yaşamaktan, ziyaretçiler daha çekici ve daha çok imkân sunan bir yeri ziyaret etmek, yerel yöneticiler ise yönetmekle sorumlu oldukları bölgenin gelişmesi ve büyümesini istemektedirler. Bu istek ortaklığı, bazen örgütlü, bilinçli ve planlı şekilde, bazen ise düzensiz ve tesadüfi şekilde destinasyonların büyümesi ve gelişmesi için ortaya bir çaba çıkarmaktadır. Bu çaba her zaman başarılı olamamaktadır. Ancak başarılı olması her zaman iyi sonuçlanmayabilmektedir. Kontrolsüz büyüyen her örgüt ve organizma gibi destinasyonlar da fazla büyümenin bedelini doğal tahribat, kültürel yozlaşma ve metalaşma, ekonomik olarak geri dönmeyen yatırımlar veya yükselen fırsat maliyeti gibi istenmeyen sonuçlarla ödemektedir. Bu gibi durumlarda destinasyon planlaması önem taşımakta, destinasyonların sürdürülebilirliği anlayışı olmazsa olmaz hale gelmektedir. Uluslararası alanyazında de-marketing olarak ifade edilen pazarlamama uygulamaları, bu gibi durumlarda kontrolsüz gelişimi yavaşlatabilmek ya da durdurabilmek adına faydalı bir araç olabilmektedir. Bu araştırmanın temel amacı, henüz kontrolsüz gelişmenin getirdiği olumsuz sonuçlar ile yüzleşmemiş bir destinasyon için olası tedbirleri belirlemek ve destinasyonun gelecekteki muhtemel olumsuzluklar ile yüzleştiğinde hazırlıklı olmasını sağlamaktır.

Turizm destinasyonları hem yerel halkın hem de turistlerin ihtiyaçlarını karşılayan sınırlı doğal kaynaklara sahiptir. Bu kaynakların dengeli ve bilinçli bir şekilde kullanımı tüm paydaşlar için önem taşımaktadır (Alagöz ve Güneş, 2019). Turizm faaliyetlerinin niteliği çevre kalitesine doğrudan bağlıdır ancak çevre kalitesinin düşmesinde turizm faaliyetlerinin etkisi olmaktadır. İnsanların kendi istek ve ihtiyaçları doğrultusunda bilinçsizce çevreyi kirletmesi ve tahrip etmesi çevrenin insana mağlup olması gibi görünse de aslında doğa karşısında mağlubiyete uğrayan insanın kendisi olmaktadır (Sonuç, 2014). Şunu anlamak gerçekten önemlidir: turizmdeki ürün ve hizmetler genellikle doğal çekiciliklerden oluşur ve bunlar vahşi yaşam, sahiller, iklim gibi unsurlardır (Robaina ve Madaleno, 2019) ve turistler ile turizm endüstrisi bu doğal kaynakları ciddi biçimde tüketmektedir (Piga, 2003).

Uzun yıllar süren gelişimler ve beraberinde gelen kazancın sonucunda bazı kentler üst limitlerine ulaşmakta ve kentteki yaşanabilirlik risk altına girmektedir. Bu durum şu soruyu beraberinde getirmektedir: Turizm sürdürülebilirliğin önünde bir engel midir yoksa sürdürülebilirliğin sağlayıcısı mıdır? (Mata, 2019). Sınırlı doğal kaynaklar sadece turizm faaliyetleri için değil ekosistemin ve doğal hayatın sürdürülebilirliği açısından da önem taşımaktadır (Ödemiş ve Çalık, 2019). Bundan ötürü sürdürülebilir turizm anlayışı hem turistler hem yerel halk için kaynakların korunması ve kullanımı açısından önem arz etmektedir (Bramwell ve Lane, 1993).

Sürdürülebilir turizm bir bölgedeki turizm faaliyetlerinde mevcut fayda ile gelecekte aynı kaynaktan fayda sağlanmasının devamına dair bir denge sağlamaya çalışır. Bu durum turizm bölgelerinde uzun vadeli planların ve düşünme şeklinin hayata geçirilmesini gerektirir (Yılmaz, 2014). Bir destinasyonun rekabet avantajı da sürdürülebilir yönetim ve anlayışa sahip olmasına bağlıdır. Ancak bu sadece ekolojik ve ekonomik perspektiften değil aynı zamanda kültürel ve politik olarak da değerlendirilmelidir (Ritchie ve Crouch, 2000).

Birçok uzmana göre kent destinasyonlarında başlıca sorunlar dijital adaptasyon, güvenlik, yeni işletme modellerine geçiş ve sürdürülebilir gelişim limitleridir (Mata, 2019). Kent destinasyonlarında aşırı gürültü ve kalabalık, uzun bekleme süreleri ve kirlilik gib sorunlar genellikle kitle turizminde kaynaklanmaktadır ve çevresel, tarihi, kültürel değerler için tehdit 
oluşturabilmektedir (Timur ve Getz, 2009). Öte yandan turizm destinasyonlarında yerel halk turizmin getirilerinden yeterince yararlanamaz ya da birincil kaynakların kullanımından mahrum kalır ise memnuniyetsizlik ortaya çıkacaktır (Tokmak, 2019). Buna ek olarak bazı destinayonlarda turistlerin saygısız davranışları ve yerel halkın buna bağlı rahatsızlıkları sonucu yerel karar vericiler turizm faaliyetlerine karşı bazı önlemler almak zorunda kalmaktadır (Becker, 2015).

Çevre koruma anlayışı bazı doğal kaynakların ve faktörlerin kullanımınının kısıtlanması anlamına gelmektedir ve bu durum talebin tam olarak karşılanamamasına neden olur. Bu durumda arz yeterli olmadığı için talebin azaltılması gerekmektedir (Bradley ve Blythe, 2014). Yukarıda bahsi geçen durumlardan dolayı Amerika Birleşik Devletleri'nde tüketicilerin taleplerini, çevreye olan olumsuz etkilerini gidermek ve azaltmaya yönelik örgütler ortaya çıkmıştır. Buy Nothing Day (Hiçbir şey satın almama günü) adı verilen örgüt pazarlamama faaliyetlerinde bulunmaktadır (O'Shaughnessy ve O'Shaughnessy, 2002).

\section{LITERATÜR}

Pazarlamama (demarketing) kavramı genel olarak talebin azaltılması ile ilgilidir ve belirli ürün ve hizmetlere olan talebi azaltma faaliyetidir (Memiş ve Cesur, 2019). Talebin az olması ile baş etmek kadar talebin fazla olması da bir sorundur ve pazarlamamaya olan ihtiyaç bir şirket için; geçici arz yetersizliği, tüketimi azaltma çabaları ve alternatiflere yönelme ihtiyacı durumlarında ortaya çıkmaktadır (Kotler ve Levy, 1999). Enflasyonun yüksek olduğu dönemlerde ve kıtlık zamanlarında işletmeler için pazarlamama faaliyetleri önerilmektedir (Shama, 1978). Turistik destinasyonlarda vandallık, grafiti ve benzeri çizimler ve geride bırakılan eşyalar ve çöpler gibi sorunlar yüzünden de başvurulan bir uygulama olabilmektedir (Groff, 1998). Birçok yazardan farklı olarak, pazarlamamanın kriz yönetiminde reaktif bir yaklaşım olarak kullanılabileceği de savunulmaktadır. Örneğin İngiltere'de 2001 yılındaki ayak ve ağız hastalığı (Foot and mouth disease) nedeniyle yerel yetkililer talebi azaltmak için pazarlamama uygulamalarına başvurmuştur (Medway, Warnably ve Dharni, 2010).

Üstteki tanıma ek olarak, pazarlamamanın 2 farklı türü daha olduğundan bahsedilmektedir. Bunlar senkronize pazarlama (synchro-marketing) (pazarın talebini üretim kapasitesine göre ayarlamak suretiyle pazarı manipüle etmek ve mevsimsel dalgalanmaları azaltmayı amaçlamak), karşı pazarlama (counter-marketing) (talebi arttırmada kullanılan pazarlama araçlarının bilinçli bir şekilde talebi azaltmak için kullanılması) (Bradley ve Blythe, 2014).

Göstermelik pazarlamama; bir marka, bir ürün ya da hizmetin sunumunun profesyoneller tarafından azaltılması ya da engellenmesidir ve ters bir şekilde ürün ya da hizmetin istenme düzeyini arttırmaktadır (Croft, 2014). Genel pazarlamama ve karşı pazarlama arasında ise ince bir çizgi bulunmaktadır. Karşı pazarlama, pazarlama faaliyetlerine karşı aktif bir faaliyet içermektedir (Bradley ve Blythe, 2014). Seçimli pazarlama faaliyetinde işletme her zaman toplam talebi azaltmayı değil, pazarın yalnızca bir bölümü ile ilgili talebi azaltmayı hedeflemektedir. Bu bölümler işletme için kârlı olmayan ya da istenmeyen bölümlerdir (Tek 1997, 55; Altınay ve Sert, 2012). Seçimli pazarlamama stratejisinde engellenmek istenen pazar bölümleri ile elde tutulmak istenen pazar bölümleri arasında işletmeler tarafından fayda-zarar analizleri yapılmalıdır (Altınay ve Sert, 2012).

Pazarlamamanın 3 farklı uygulamasından söz edilmektedir. Bunlar; 
- Genel pazarlamama (bir şirketin toplam üretim ve talep seviyesinin azaltılmaya çalışılması)

- Seçimli pazarlamama (bir şirketin belirli bir müşteri grubu veya pazar payının talebini azaltmaya yönelik çabalar)

- Gerçek olmayan-göstermelik pazarlamama (talebi azaltmaya çalışıyor gibi görünerek aslında talebin arttırılması çabası)

- Yukarıdaki üçlüye ek olarak istenmeden yapılan pazarlamama faaliyetlerinden de bahsedilebilir. Şirket satışlarını arttırmak isterken yoğun pazarlama faaliyeti sonrası talebini düşürebilir (Kotler ve Levy, 1999).

Pazarlamama karışımı dikkatli bir şekilde oluşturulmalıdır. Bir işletme bunu yaparken, ürün veya hizmetin sınırlı sayıda üretildiği izlenimini verebilir, istenmeyen gruplara düşük kalite hizmet sunulabilir. Örnek olarak ailelere hizmet vermeyi tercih etmeyen bir konaklama işletmesi çok çocuklu ailelere dekorasyonu yenilenmemiş ya da binanın uç noktalarında yer alan odaları verebilir (Sezer, 2000). Pazarlama karması öğelerinde "fiyat" pazarlamama faaliyetleri için de kullanılabilir. Fiyat ayrımcılığı ile talebin caydırılması etkili bir şekilde kullanılabilir (Bozacı, 2016).

Pazarlama faaliyetleri; uygun olmayan mekânların seçilmesi, stok seviyelerinin düşük tutulması, reklam ve tutundurma faaliyetlerinin azaltılması, ürünlerin faydalı özelliklerinin çıkarılması, mağaza ve satış çalışmalarının eksiltilmesi şeklinde de uygulanabilir (Miklos-Thal ve Zhang, 2013). Pazarlamama araştırmalarının sıkça yapıldığı kumar alışkanlığına dair öneri ve uygulamalar ise şu şekildedir: ürün arzının sınırlandırılması, mekânlara erişimin zorlaştırılması, reklam faaliyetlerinin azaltılması ve daha iyi bilgilendirme sunmak (saat bilgisi, kazanılankaybedilen miktarın belirtilmesi vs.) (Beeton ve Pinge, 2003). Havitz, McLean ve Adkins (2008) yaptıkları araştırmada pazarlamama faaliyetleri esnasında pazar bölümlendirmenin önemine vurgu yapmaktadir.

Pazarlamama faaliyetlerinin sağlık alanındaki başarıları göz önüne alındığında, bu yaklaşımı kaynakların kıt olduğu servis endüstrilerinde kullanmak akıllıca bir adım olacaktır (Beeton ve Benfield, 2002). Gerçekten de turizm endüstrisi doğal çekicilik unsuru olarak yeryüzündeki kaynaklara bağımlı durumdadır ve bu kaynaklar ölçüsüz kullanım sonucu kalıcı olarak hasar görebilmektedir. Wearing ve Neil (1999) bununla ilgili olarak, pazarlamama yaklaşımının ekoturizmde kıt kaynakların korunması için faydalı bir araç olacağını belirmektedir. Buna ek olarak park ve rekreasyon bölgelerinde talep kaynaklı sorunların çözümünde de faydalı bir yaklaşım olacağı düşünülmektedir (Groff, 1998).

Avustralya'da yapılan araştırma göstermektedir ki daha önce yapılan pek çok araştırmanın desteklediği gibi pazarlamama yaklaşımı bölgenin koruma altındaki alanlarını turizm sebepli bozulmalara karşı koruma anlamında etkili olmaktadır (Armstrong ve Kern, 2011). Tüketicilerde çevre koruma tutumunun oluşması ve buna bağlı olarak tüketim karşıtlığı algısı oluşmasıyla birlikte pazarlamacılar da bu doğrultuda bir tutum geliştirmeye ve pazarlamama faaliyetlerine yönelmeye başlamışlardır (Belz ve Peattie, 2012).

\section{YÖNTEM}

Bu çalışma önleyici bir çalışma olarak tasarlanmıştır. Bir olgunun vakaya dönüşmesi öncesinde öneriler sunmayı amaçlamaktadır. Çalışmanın amacına ulaşması ve geçerliliği için hem ilgili alanyazından hem de çalışmanın kapsadığı alandan veriler toplanmıştır. Çalışma Sapanca ilçesini kapsamaktadır ve sahadan elde edilen veriler araştırmacılar tarafından katılımcı olmayan gözlem yöntemiyle toplanmıştır. Alanyazından toplanan veriler ise araştırmanın konusu ve 
kapsamı ile alakalı olarak ulusal ve uluslararası yayınlardan elde edilmiştir. Elde edilen bu veriler gözlemler öncesinde yol gösterici ve gözlem hususlarını belirleyici olmuştur.

Gözlem ile verilerin elde edilmesi aşaması 2019 yaz, sonbahar ve kış aylarını kapsamaktadır. Sapanca ilçesi turizm faaliyetlerinin belirli dönemlerde yoğunlaştığı bir destinasyon değildir. Buna rağmen, gözlem verilerinin mevsimsel olarak aldatıcı olmasını önlemek amacıyla veri toplama süresi uzatılmıştır.

\section{BULGULAR}

Sapanca ilçesinde turizm hareketlerinin dört mevsim boyunca devam ettiği görülmektedir. Buna rağmen, tatil dönemleri ve mevsimsel geçiş zamanlarında bazı yoğunlaşmalar olmaktadır. Sonbahar mevsiminde yayla destinasyonları, kış döneminde karlı destinasyonlar ile yaz tatilinde göl kenarı destinasyonlarda yerel yoğunluklar gözlenebilmektedir. Sapanca destinasyonunun turistik anlamda asıl çekicilik unsurları göl kenarında konumlanması ve sahip olduğu yaylalarıdır. Sapanca, coğrafi olarak İstanbul, Bursa ve Ankara gibi turist gönderen büyük yerleşim birimlerine kolay ulaşılabilir konumdadır. Bölgeye gelen yerli turistlerin büyük bölümünün bu yerleşim yerlerinden geldiği anlaşılmaktadır. Öte yandan bölgede yerleşik olarak ikamet etmekte ola çok sayıda Ortadoğu kökenli vatandaş ve kişi bulunmaktadır. Bu durum Sapanca destinasyonunu Arap turistlerin de sıkça ziyaret ettiği bir çekim merkezi haline getirmektedir.

Sapanca'nın hemen doğusunda Uzunkum Mahallesi yer almaktadır ve orman özelliklerine sahip ve bir mesire yeri ile göl kenarı mesire yerlerine sahiptir. Batı istikametinde ise Kırkpınar Mahallesi yer almaktadır. Kırkpınar, Sapanca destinasyonunda bulunan konaklama ve yiyecekiçecek işletmelerinin çoğunluğuna ev sahipliği yapmaktadır. Daha da batıya gidildiğinde Sapanca'dan 20 kilometre mesafede Kartepe Kış Turizmi merkezi bulunmaktadır. Kartepe ilçesi sınırlarında bulunan bu destinasyon aslında Sapanca ilçesi sınırlarının ve bu araştırmanın kapsamının dışındadır. Ancak Sapanca destinasyonuyla olan olası ilgili nedeniyle bölgede gözlemler yapılmış ve gözlem sonuçları Sapanca ile olan ilgili ileriki bölümlerde ifade edilmiştir.

Ulaşım ve ulaşılabilirlik imkânlarına bakıldığında, Sapanca destinasyonu sadece karayolu ile ulaşıma elverişli görülmektedir. Sapanca'da toplu ulaşım araçları için bir otogar bulunmamaktadır. Yolcular ilçe merkezindeki otobüs durakları vasıtası ile toplu ulaşım araçlarını kullanmaktadırlar. Sapanca ilçe merkezinde, Sakarya kent merkezine ve Kocaeli kent merkezine doğrudan ulaşım imkânı veren toplu ulaşım araçları mevcuttur. Öte yandan İstanbulAnkara otoyolu şehir trafiğine kapalı olmak suretiyle Sapanca üzerinden geçmektedir ve Sapanca ilçesi ile bağlantı sağlayan giriş-çıkış gişeleri mevcuttur. Sapanca ilçe merkezi, Kocaeli kent merkezine toplu ulaşım vasıtaları ile 45-60 dakika, Sakarya kent merkezine toplu ulaşım vasitaları ile 30-45 dakika sürmektedir.

Ulaşımla ilgili karayollarının fiziki durumuna bakmak daha aydınlatıcı olacaktır. Bu kapsamda araştırmacılar hususi araçları ile Sapanca'nın bağlantı yolları ile başlıca çekiciliklerini farklı saatlerde ve zamanlarda ziyaret etmişlerdir. Sapanca'nın Sakarya kent merkezi ve Kocaeli kent merkezi ile olan karayolları eski tip çift yönlü karayolu şeklindedir. Bu yollarda hem trafik kuralları hem yolların fiziki durumu nedeniyle saatte 50-70 kilometre hizla seyretmek mümkündür. Bahsi geçen yolların tamamına yakını yerleşim yerleri içerisinde kalmaktadır. Bu nedenle ulaşımda aksamalar görülmekte, turistik amaçlı seyahatler ilçe içi ulaşımı da yavaşlatmakta, ses ve hava kirliliğine neden olmaktadır. Aynı genişlik ve asfalt kaplama yollara Sapanca içi çekim merkezlerinde de rastlanmaktadır. Uzunkum bölgesine, Kırkpınar bölgesine 
ve ilçe merkezindeki göl kenarına ulaşım sağlayan yollar asfalt kaplama olsa da 2 aracın yan yana ancak geçebileceği genişliktedir. Yollarda hız kesici tümseklerin fazlalığı dikkat çekmektedir.

Sapanca'nın güney istikametinde kalan yayların ulaşımı ise coğrafi şartlarından ötürü daha zorludur. Yaylalara ulaşım sağlayan yolların çoğu yan yana 2 aracın geçmekte zorlanabileceği genişliktedir ve yolun asfalt kaplamalarında deformasyon görülmektedir. Yolların bazı bölümlerinin stabilize konumda kaldığı ve toprak olduğu görülmüştür.

Yukarıda bahsi geçen tüm karayollarında, cuma günleri başlayan, cumartesi ve pazar günleri zirve yapan yoğunluklar görülmektedir. Bahsi geçen günlerde özellikle Kırkpınar ve Kartepe istikametinde trafik ciddi ölçüde yavaşlamaktadır. Kırkpınar sahil ve Sapanca sahil kesimlerinde park yeri sorunu baş göstermektedir. Birçok konaklama ve yiyecek-içecek işletmesi özel park yerleri ile misafirlerine hizmet sunmaya çalışmaktadır ancak bunlar dışında araç park alanı bulmak zor olmaktadır. Özellikle Sapanca ilçe merkezindeki göl kenarı kesimlerde girişin yasak olduğu sokaklar ile park yasakları dikkat çekmektedir.

Konaklama işletmelerinin çoğunluğunun Kırkpınar mevkiinde konumlandığı daha önce belirtilmişti. Bu bölgedeki işletmelerin büyük çoğunluğunun butik otel olarak yapılandığ 1 görülmektedir. İşletmelerin çoğunluğu sayfiye oteli olarak hizmet vermekte bunun yanında büyük otellerin bazllarının wellness ve spa konseptinde hizmet verdiği görülmektedir. Sapanca' da gerek yeni turizm işletmelerinin gerek yerleşim amaçlı yapılanmanın, ilçenin güney kesimindeki tepeliklerin yamaçlarına doğru ilerlediği görülmektedir. Bahsi geçen yamaçlar, bölgenin güneyini kapsayan dağların etekleridir ve bitki örtüsü ve doğal yaşam alanıdır.

Yiyecek-içecek işletmelerinin büyük çoğunluğunun göl kenarı bölgelerde konumlandığı ve kümelenme gösterdiği görülmektedir. İlgili işletmelerin kahvaltı, akşam yemeği, toplu davet ve yemek organizasyonları gibi farklı hizmetler cevap verebilecek nitelikte olduğu görülmektedir. İşletmeler konumları itibariyle peyzaj çekicilikler sunmaktadır. İşletmelerin fiyat tabelaları ve menüleri gözlenmiştir. Kahvaltı menülerinin kişi başı 30-80 Türk Lirası, sıcak meşrubatların 5-20 TL, ortalama bir akşam yemeği fiyatının kişi başı 40-120 TL, toplu bir organizasyonda ise kişi başı menü fiyatının 30-80 TL arasında olduğu gözlenmiştir. İlgili işletmelerin birçoğunda Türkçe ve Arapça tabelaların varlı̆̆ı görülmüştür.

Araştırmanın sınırları içerisinde bulunmayan Kartepe destinasyonuna yapılan ziyaret sonrasında bölgedeki fiziki taşıma kapasitesinin fazlasıyla aşıldığı anlaşılmaktadır. Bu durum, Kartepe'yi ziyaret eden turistlerin, yakınlığı itibariyle Sapanca'daki konaklama, yiyecek-içecek ve rekreasyon işletmelerinden yararlandığı sonucunu doğurmuştur.

Sapanca destinasyonundaki rekreasyon ve boş zaman değerlendirme tesislerinin ağırlıklı olarak mesire yerleri ve doğal alanlar olduğu görülmektedir. Uzunkum mevkiinde tabiat parkı ve göl kenarı piknik alanı, ilçe merkezinde göl kenarı sahil ve yürüyüş yolları, Kırkpınar mevkiinde göl kenarı sahil ve yürüyüş yolları bulunmaktadır. Bu bölgelerde araştırmayla ilgili gözlemlerin yapıldığı esnada ciddi bir yoğunluk gözlenmemiştir. Sapanca ilçe merkezindeki göl sahili dışında park yeri sorununa da rastlanmamıştır. Araştırmanın veri toplama aşamasında Kırkpınar'da kadınların ev yapımı çeşitli ürünlerini sergilediği ve sattığı bir festival düzenlenmiştir. Festivalde 2 gün boyunca yapılan gözlemlerde aşırı bir yoğunluğa rastlanmamış, ulaşım ya da park yeri sorunu gözlenmemiş, festival kırsal bir etkinlik olarak düzenlenmiş ve tamamlanmıştır.

\section{TARTIŞMA, SONUÇ ve ÖNERILLER}

Yapılan saha gözlemlerinde, Sapanca destinasyonunun birden fazla turistik çekim unsuruna sahip olduğu ve birden fazla turist grubunu ağırladığı görülmektedir. Bu durum destinasyonun 
tek bir turizm türüne ya da tek bir turist grubuna olan bağımlı olmadığını, gelecekte de bu ihtimalin düşük olduğu sonucunu çıarmaktadır.

Gözlemler göstermektedir ki, Sapanca destinasyonu beşeri değil doğal turizm arzına sahip bulunmaktadır. Bu durum, doğal kaynakların turizm amaçlı olarak kullanılması ve bu kaynakların sürdürülebilir ilkeler dışında kullanılması durumunda tahrip edilme olasılığ sonucunu doğurmaktadır. Turizmin sürdürülebilir ilkeler doğrultusunda planlanması, yönetilmesi ve pazarlanması, destinasyonla ilgili ilk ve öncelikli öneri olarak öne çıkmaktadır. Alanyazında bununla ilgili olarak eko-yenilikçilik ve eko-etkili planlama kavramları yer almaktadır. Eko-yenilikçilik, çevreye verilen zararı azaltmak ya da önlemek amaçlı olarak yeni üretilmiş ya da geliştirilmiş ürünler, teknikler ve yönetim sistemleri olarak tanımlanmaktadır (Ghisetti vd., 2015). Eko-etkili planlama stratejileri turistleri iki farklı şekilde etkilemektedir. Daha az yoğunluk ve trafik olumlu etkilere örnek olarak verilebilirken, kısıtlanmış erişim olumsuz bir etki olarak gösterilebilir (Robaina ve Madaleno, 2019).

Ulaşılabilirlik anlamında destinasyonun vermesi gereken bir karar mevcuttur ve bu durum bir ikilem yaratmaktadır. Ulaşım olanaklarının ve özellikle destinasyon sınırları içerisindeki karayollarının mevcut kapasitelerinin korunması ve genişletme çabalarına başvurulmaması, turizm hareketliliğinin pazarlamama faaliyetlerine ihtiyaç duyacak ölçüde olumsuz bir noktaya gelmesini önleyici olabilecektir. Öte yandan bu tedbirin tek başına yeterli olmaması durumunda, destinasyondaki yaşam kalitesi yerel halk için düşeceği gibi, ziyaretçilerin deneyim kalitesinde de düşüşler görülecektir.

Sapanca' daki konaklama işletmelerinin sayısının ve destinasyondaki toplam yatak kapasitesinin arttırılmaması önem taşımaktadır. Bulgular bölümünde değinildiği gibi destinasyondaki konaklama işletmelerinin bir bölümü esenlik ve spa konseptinde hizmet verirken, bir bölümünün butik otel işletmesi olarak faaliyetlerini sürdürdügü belirtilmiştir. Konaklama işletmelerinin ya da yatak kapasitesinin arttırılması, işletmeler arasındaki rekabeti arttıracak, hizmet kalitesini ve fiyatları düşürecek ve bölge nitelikli ve çevre duyarlı turistlerin yanı sıra bu konularda duyarsız olarak nitelenebilecek ziyaretçileri de çekebilecektir.

Bir bölgeyi ziyaret eden turistlere, bölgenin korunması ve turizm faaliyetlerinin sürdürülebilir sınırlar içerisinde yapılmasına dair bilgilendirme yapmak ve bunu da tam yerinde ve tam zamanında ilkesi gereği destinasyonda yapmak çokça dile getirilen bir öneridir. Bununla beraber Inness vd., (2007) sigaranın bıraktırılmasına dair pazarlamama faaliyetlerinin etkileri üzerine yaptıkları çalışmada, nikotini bırakmaya dair terapilere olan ilginin artmaya başladığını ancak bunun geçici olduğu ve 3 ay sonra sigaraya olan talebin, araştırma konusu deneklerde tekrar eski haline döndüğünü gözlemlemişlerdir. Bu durum bahsi geçen sürdürülebilirlik temalı telkin çalışmalarının başarısına kuşkuyla bakılmasına neden olmaktadır. Böyle bir çabanın turizm faaliyetlerindeki etkilerine dair bir araştırmaya ise rastlanmamıştır.

Ayar (2019) gençlerin gıda tüketimi ve bu konudaki pazarlamama çalışmalarına üzerine yaptığ araştırmada, sinırlı mal ve hizmet sunumu ve yüksek fiyatlandırma gibi önlemlere vurgu yapmaktadır. Benzer bir uygulama Sapanca destinasyonu için uygulanabilir görülmektedir. Destinasyon kapsamında; ölçüsüz turizm faaliyetlerine sebep olabilecek gelişmeleri önlemek için, bazı hizmetlerin erişiminin zorlaştırılması, fiyatlarının arttırılması faydalı olabilecektir. Bu konuda yeni kurulacak konaklama ve yiyecek-içecek işletmeleri için kamu teşviklerinin azaltılması ve hatta aksi yönde maliyetleri yükseltici tedbirlerin alınması faydalı olabilecektir. Bu öneriye benzer olarak Shiu, Hassan ve Walsh (2009) kamu karar alıcılarının özellikle vergi müdahaleleri ile pazarlamama faaliyetlerine katkı sunabileceğini ve bunun tütün tüketiminin azaltılması çalışmalarında kullanıldığını belirtmektedir. 
Yerel halkın turizme bakış açısı, turizmden faydalanması ile doğru, turizmden duyduğu rahatsızlık ile ters orantılıdır. Turizm faaliyetlerinden duyulan rahatsızlıklar genellikle sinsice gelişen hastalıklar gibidir ve doruk noktaya ulaşana kadar çok fazla belirti göstermezler. Doruk noktaya ulaştığında ise bir hastalık biri ciddi semptomlar gösterirler ve olumsuz durumlara yol açarlar. Bunun önüne geçilmesi için, sosyal taşıma kapasitelerine dair periyodik olarak saha çalışmalarının yapılması faydalı olacaktır. Sapanca destinasyonu, Batı Karadeniz ve Doğu Marmara coğrafi konumlarının kültürel özelliklerini taşıyan ve kozmopolit olmayan bir destinasyondur. Bu nedenle turizm faaliyetlerinden doğabilecek her türlü kültürel ve sosyal değişime hızlıca adapte olması çok olağan değildir. Turizm hareketlerinin gelişimi izlenirken bu gerçeğin göz önünde bulundurulması gerekmektedir.

Sapanca için, karşı pazarlama (counter-marketing) faaliyetleri için, yerel halkın kendi değerlerini koruması içgüdüsü tetiklenerek oto-kontrol mekanizması hayata geçirilebilir. Özellikle bulgular kısmında belirtildiği gibi, turizm amaçlı yerleşimin bölgenin ormanlık alanlarına doğru yönelmesi, gelecekte bazı olumsuz bazı çevresel etkiler doğurabilecektir. Bu kapsamda çevresel duyarlılığ mekanizmasını hayata geçirmekte etkili olabilecektir.

Seçici pazarlamama (selective de-marketing) anlamında, yazarların belirli bir pazar bölümünü ya da turist grubunu işaret etmeleri eldeki mevcut veriler ile mümkün değildir. Destinasyonun katılımcı ve sürdürülebilir yönetimi gereği, ilgili pazar bölümlerinin ve turist gruplarının; ekonomik, kültürel, sosyal etkileri detaylıca analiz edilmeli ve bunların gelecekteki durumları göz önüne alarak paydaşlar nezdinde karar verilmelidir. Ancak bu hususta, gelecekteki durumun göz önüne alınması gerekliliğinin altını çizmekte fayda vardır. Turizm talebi, esnek yapısı itibariyle işletmeler ve destinasyonlar için kontrolü zor bir yapıdadır. Seçici olarak bir gruba uygulanacak pazarlamama çalışmaları, hedeflenen grubun talebinde beklenmeyen bir düşüş olması durumunda destinasyonu zor durumda birakacak "Dimyat'a pirince giderken eldeki bulgurdan olmak" deyimini ile ifade edilen durumla baş başa kalınmasına sebebiyet verebilecektir.

Taşıma kapasitelerinin aşılması halinde uygulanabilecek bir diğer çözüm, katı kısıtlamalara gidilmesidir. Bazı cadde ve sokakların taşıt trafiğine kapatılması, bazı araç türlerinin girişlerinin tamamen yasaklanması (örneğin off-road taşıtlarının yasaklanarak yayla ve benzeri alanların korunması ya da tur otobüslerinin girişinin engellenerek kitle turizmine yönelik faaliyetlerin azaltılmaya çalışılması gibi) uygulanabilecek önlemler arasındadır. Bunlara ek olarak, haftanın bazı günlerinin "halk günü" olarak ilan edilmesi ve ilgili günlerde bazı çekim noktalarının sadece yerel halka hizmet verecek şekilde düzenlenmesi de alternatifler arasında yer alabilir.

Katı kısıtlamalara ek olarak, caydırıcı bazı tedbirlerin de hayata geçirilmesi mümkün olabilmektedir. Birçok Avrupa kentinde, turist vergisi, turizm vergisi ve müze-ören yeri giriş ücretleri uygulamaları yapıldığı bilinmektedir. Cüzi sayılabilecek miktarlar ücret talep edilmesi, turistik çekim unsurunun kendisinden ziyade ücrete duyarlı turistleri caydıracak ancak ilgili çekim unsuruna gerçekten ilgi duyan ve bununla beraber turistik çekimin korunması için duyarlılığı olan turistlerin ziyaretlerine engel olmayacaktır.

Sapanca destinasyonunun, bu araştırmanın yapıldığı ve yazıldığı dönemde, pazarlamama faaliyetlerine ihtiyaç duyup duymadığı, bu araştırmanın kapsamının ötesindedir. Araştırmacıların sezgisel gözlemleri henüz bu aşamaya gerek olmadığı yönünde olsa da bunun tespiti için, taşıma kapasitelerini incelemeyi içeren daha geniş kapsamlı çalışmalara ihtiyaç duyulmaktadır. Bununla birlikte Sapanca destinasyonunun, destinasyon yaşam evresinin hangi aşamasında olduğunu tespite yönelik araştırmalara ihtiyaç bulunmaktadır. Bu araştırmaların 
sonuçlarına göre, destinasyon için daha geçerli planlama ve pazarlama yaklaşımları geliştirmek mümkün olacaktır.

\section{KAYNAKÇA}

Alagöz, G. ve Güneş, E. (2019). Turizm Faaliyetlerinin Sınırlandırılmasında Turizm Göstergeleri ve Taşıma Kapasitesi. O. Türkay içinde, Sürdürülebilir Turizm: Gösterge Geliştirme ve Ölçme Yaklaşımı (s. 357-377). Ankara: Detay Yayıncılık.

Altınay, A. ve Sert, S. (2012). Pazarlasak da mı Satsak Pazarlamasak da mı Satsak? Pazarlamada Yeni Bir Boyut: De-Marketing (Pazarlamama) Kavramı. Sosyal ve Beşeri Bilimler Dergisi, 4(1), 6773.

Armstrong, E. K., and Kern, C. L. (2011). Demarketing Manages visitor Demand in the Blue Mountains National Park. Journal of Ecotourism, 10(1), 21-37.

Ayar, İ. (2019). Pazarlamama Kavramı ve GEnçlerin Gıda Tüketim tercihleri Üzerine Bir Araştırma. İşletme Araştırmaları Dergisi, 11(1), 545-557.

Becker, E. (2015). The Revolt Against Tourism. The New York Times.

Beeton, S., and Benfield, R. (2002). Demand Control: The Case for Demarketing As A Visitor and Environmental Management Tool. Journal of Sustainable Tourism, 10(6), 497-513.

Beeton, S., and Pinge, I. (2003). Casting the Holiday Dice: Demarketing Gambling to Encourage Local Tourism. Current Issues in Tourism, 6(4), 309-322.

Belz, F. M., and Peattie, K. (2012). Sustainability Marketing: A Global Perspective (2nd edition). Chichester: John Wiley \& Sons.

Bozacı, İ. (2016). Seçici Pazarlamama (Demarketing) Algılamaları ile Müşteri Tutumları İlişkisi: Genç Tüketiciler İle Gerçekleştirile Bir Saha Çalışması. Uluslararası Sosyal Araştırmalar Dergisi, 9(43), 2548-2556.

Bradley, N., and Blythe, J. (2014). Demarketing and Marketing. N. Bradley, \& J. Blythe içinde, Demarketing (s. 212-217). London and New York: Routledge.

Bramwell, B., and Lane, B. (1993). Sustainable Tourism: An Evolving Global Approach. Journal of Sustainable Tourism, 1(1), 1-5.

Croft, R. (2014). Ostensible Marketing. N. Bradley, \& J. Blythe içinde, Demarketing (s. 150-163). London and New York: Routledge.

Ghisetti, C., Mazzanti, M., Mancinelli, S., and Zoli, M. (2015). Do Financial Constraints Make the Environment Worse off? Understanding the Effects of Financial Barriers on Environmental Innovations. SEEDS (Sustainability Environmental Economics and Dynamics Studies).

Groff, C. (1998). Demarketing in Park and Recreation Management. Managing Leisure, 3(3), 128135.

Havitz, M. E., McLean, D. J., and Adkins, K. D. (2008). The Influence of Market Segment Information on Professionals' Demarketing Preferences for Municipal Golf Services. Leisure/Loisir, 32(2), 573-592.

Inness, M., Barling, J., Rogers, K., and Turner, N. (2007). De-Marketing Tobacco Through Price changes and Consumer Attenpts to Quit Smoking. Journal of Business Ethics(77), 405-416.

Kotler, P., and Levy, S. J. (1999). Demarketing, Yes, Demarketing. Harvard Business Review, 79(1), 74-80. 
Mata, J. (2019). Intelligence and Innovation for City Tourism Sustainability. E. Fayos-Sola, \& C. Cooper içinde, The Future of Tourism: Innovation and Sustainability (s. 213-232). Springer.

Medway, D., Warnably, G., and Dharni, S. (2010). Demarketing Places: Rationales and Strategies. Journal of Marketing Management, 27(1-2), 124-142.

Memiş, S., ve Cesur, Z. (2019). Devletin Sosyal Amaçlı Sigara Kullanımını Azaltmaya Yönelik Pazarlamama (Demarketing) Uygulamalarının Tüketiciler Üzerindeki Etkisi. Üçcüncü Sektör Sosyal Ekonomi Dergisi, 54(1), 108-121.

Miklos-Thal, J., and Zhang, J. (2013). Demarketing to Manage Consumer Quality Inferences. Journal of Marketing Research, 50(1), 55-69.

O'Shaughnessy, J., and O'Shaughnessy, N. (2002). Marketing the Consumer Society and Hedonism. European Journal of Marketing, 36(5), 524-547.

Ödemiş, M., ve Çalık, İ. (2019). Sürdürülebilir Turizm Kavramı, Tarihsel Gelişimi ve Göstergeler Yoluyla İncelenmesi. O. Türkay, ve İ. Çalık içinde, Sürdürülebilir Turizm: Gösterge Geliştirme ve Ölçme Yaklaşımı (s. 2-36). Ankara: Detay Yayıncllık.

Piga, C. A. (2003). Pigouvian Taxation in Tourism. Environemntal and Resource Economics, 26(3), 343-359.

Ritchie, J. R., and Crouch, G. I. (2000). The Competitive Destination: A Sustainability Approach. Tourism Management, 21(1), 1-7.

Robaina, M., and Madaleno, M. (2019). Resources: Eco-Efficency, Sustainability and Innovation in Tourism. E. Fayos-Sola, \& C. Cooper içinde, The Future of Tourism Innovation and Sustainability (s. 19-41). Springer.

Sezer, İ. F. (2000). Pazarlamama Kavramı ve Sosyal Pazarlama Konularında Kullanımı. M.Ü. İktisadi İdari Bilimler Fakültesi Dergisi, 16(1), 333-339.

Shama, A. (1978). Management and Consumers In An Era of Stagflation. Journal of Marketing, 42, 43-52.

Shiu, E., Hassan, L. M., and Walsh, G. (2009). Demarketing Tobacco Through Govermental Policies-The 4Ps Revisited. Journal of Business Research, 62(2), 269-278.

Sonuç, N. (2014). Sürdürülebilir Turizm: Tanımı ve İçeriği. M. Kozak içinde, Sürdürülebilir Turizm Kavramlar Uygulamalar (s. 13-28). Ankara: Detay Yayıncilık.

Tek, Ö. B. (1997). Pazarlama İlkeleri Global Yönetimsel Yaklaşım Türkiy Uygulamaları 7. Baskı. İzmir: Cem Ofset.

Timur, S., and Getz, D. (2009). Sustainable Tourism Development: How Do Destinations' Stakeholders Perceive Sustainable Urban Tourism? Sustainable Development, 17, 220-232.

Tokmak, C. (2019). Sürdürülebilir Turizmde Yerel Memnuniyet. O. Türkay, ve İ. Çalık içinde, Sürdürülebilir Turizm: Gösterge Geliştirme ve Ölçme Yaklaşımı (s. 231-242). Ankara: Detay Yayıncılık.

Wearing, S., and Neil, J. (1999). Ecotourism: Impacts, Potentials and Possibilities. Oxford: Butterworth Heinemann.

Yılmaz, Ö. D. (2014). Sürdürülebilir Turizm ve Destinasyon Yönetimi. M. Kozak içinde, Sürdürülebilir Turizm Kavramlar Uygulamalar (s. 275-292). Ankara: Detay Yayıncllı. 